\title{
REVIEW
}

by Ravi PARIHAR

Shri Mata Vaishno Devi University, Katra, India*

raviparihar1988@rediffmail.com

DWIVEDI, Amitabh Vikram (2012) A Grammar of Hadoti, Munich: Lincom Europa, $127 \mathrm{pp}$.

\section{Introduction to Hadoti}

A Grammar of Hadoti is a descriptive grammar of a macro-language spoken in Rajasthan state in the Republic of India. Hadoti falls under the Indo-Aryan language family. The text has five chapters of equal length. In addition, appendices, tables, maps, and a list of references also support the book.

Chapter 1, 'Introduction' (pp. 1-5), discusses the geography, speakers, status, and lexical similarity of Hadoti. In Rajasthan, this language is spoken in districts namely Baran, Bundi, Jhalawar, and Kota respectively. This language is spoken by 8 million speakers (Census of India 2011). Hadoti is genetically an unclassified language as its affiliation has not been established till date. The native speakers use Hadoti as their mother tongue and Hindi as a lingua franca in their Hadoti region. Constituent order of Hadoti is $\mathrm{APV}^{1}$ (for transitive)/SV (for intransitive) order that comes under ergativeabsolutive (ERG-ABSL) languages, mentioning the perfectivity and volitionality for [nc] postpositional ergative marker (Dixon 1994). Therefore, the word order for Hadoti is SOV type. Hadoti shows its highest lexical similarity (64\%) with Dhundari, a language spoken in Jaipur, and least similarity (45 \%) with Mewari and Sipari each.

\footnotetext{
* Department of Languages and Literature, Shri Mata Vaishno Devi University, Katra, Jammu and Kashmir, India, 182320.

${ }^{1}$ ' $A$ ' is the most agents like argument of a multi-argument clause, which is sometimes referred to as a transitive clause. ' $P$ ' is the most patient like argument of a multi-argument clause, and ' $S$ ' is the nominal argument of a single-argument clause referred to as intransitive clause. Here ' $V$ ' is the verb for both transitive and intransitive clauses.
} 
In section 'Hadoti: Speakers and Geography', Dwivedi claims that Hadoti is spoken in four districts of Rajasthan namely, Kota, Bundi, Jhalawar, and Barn. Besides this, he also states that all the eight languages of Rajasthani region have been derived from Surseni Apbhransha. ${ }^{2}$ In addition to Hadoti, other seven languages spoken in Rajasthani region are Bagri, Shekawati, Wagari, Dhundhari, Mewati, Marwari, and Mewari. All of these are spoken in different geographical areas such as Ganganagar and Hanumangarh (Bagri); Jhunjunu and Sikar (Shekawati); Banaswara, Dungarpur, and Chitorgarh (Wagari); Jaipur, Tonk, and Sawai Madhavpur (Dhundhari); Alwar, Bharatpur, and Dholpur (Mewati); Jodhpur, Bikaner, Barmer, Jaisalmer, Churu, Pali, Ajmer, and Nagaur (Marwari); and Udaipur and Rajsamand (Mewari). Section 'unclassified languages' highlights that out of these 8 languages, only 3 languages namely, Bagri, Wagari, and Hadoti are living and unclassified ones (p. 1). For accomplishing the study, the author of the manuscript collected data from native speakers of Hadoti region. The data were collected from all kinds of speakers such as poets, students, farmers, housewives, literate, and illiterate speakers. In this book, an analytical description of phonological, morphological, and syntactical aspects of Hadoti have been provided (p. 5).

\section{Hadoti Phonology}

Chapter 2, 'Phonology' (pp. 6-23), talks about phonemic inventories of Hadoti; containing 36 consonant sounds and 10 vowel sounds, including phonological processes. Sounds $/ \mathrm{h} /$ and $/ \mathrm{h} /$ do not occur at word initial and word final positions.

Hadoti has only two fricative sounds: one is voiceless alveolar fricative /s/ and other is voiceless glottal fricative $/ \mathrm{h} /$, which is a major distinction from other IndoAryan languages like Hindi and Gujarati, which have four fricatives /s/, / / /, /s/, and /h/. Sounds such as retroflex nasal $/ \mathfrak{W}$, palatal nasal $/ \mathrm{n} /$, velar nasal $/ \mathrm{h} /$, and retroflex lateral fricative $/ V$ do not take word initial position. Rests of the consonants are shown

\footnotetext{
2 Dwivedi (2015) mentions Surseni Apbhransha as a language spoken in ancient India and its word order is Subject-Object-Verb (SOV) type.
} 
occurring in all three positions, word initial (WI), word middle (WM) and word final (WF) respectively (pp. 7-10).

The section 'consonant clusters (CCS)' discusses three kinds of CCs based on their positions. Firstly, word initial $\mathrm{CCs}(\mathrm{CC}+\mathrm{V})$ show different combinations for two consonants occurring before the nucleus. Secondly, word medial CCs (V-CC-V) have various combinations for consonants occurring in between two nucleuses. Thirdly, word final CCs (V-CC) also show diverse combinations for consonants taking positions after the nucleus (pp. 10-15).

Phonemic contrasts of Hadoti consonants such as stops /p, t, k, b, d, g/; affricates $/ t \int, d_{3} / ;$ retroflex $/ t, t^{h}, d, d^{h} / ;$ nasals $/ n, n, m / ;$ semi-vowels $/ w, j / ;$ trill $/ r /$ and fricatives /s, h/ are shown at word initial (WI), word medial (WM), and word final (WF) positions respectively (pp. 16-17).

Hadoti consonants undergo gemination with exception of retroflex lateral fricativ e $/ V$, glottal fricative $/ \mathrm{h} /$, velar nasal $/ \mathrm{h} /$, and palatal nasal $/ \mathrm{h} /$ consonants. The author states that gemination of two aspirated consonants makes the initial consonant

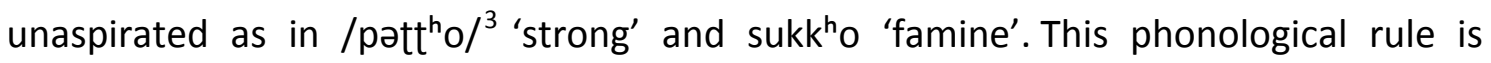
applicable to all the aspirated Hadoti consonants, such as $/ \mathrm{k}^{\mathrm{h}} /, / \mathrm{g}^{\mathrm{h}} /, / \mathrm{t} \mathrm{h}^{\mathrm{h}} /, / \mathrm{d} 3^{\mathrm{h}} /, / \mathrm{t}^{\mathrm{h}} /$, $/ \mathrm{d}^{\mathrm{h}} /, / \mathrm{p}^{\mathrm{h}} /, / \mathrm{b}^{\mathrm{h}} /, / \mathrm{t}^{\mathrm{h}} /$, and $/ \mathrm{d}^{\mathrm{h}} /(\mathrm{p} .17)$.

Vowels in Hadoti do not show any obstruction while articulating. Vowel nasalization is also found in Hadoti. In section 'vowel distribution', vowels are categorized in two categories: oral and nasal. Oral vowels are produced without nasalization when the velum blocks the nasal passage, and the nasal vowels are produced by lowering the velum as the air escapes through the nasal cavities as well as the mouth (pp. 19-20). Vowel contrasts have also been discussed showing 'oral vowels' for front, central and back tong positions individually. Whereas 'nasal vowels' are obtained when a tilde ' ' is placed above the oral vowel as in / $/$ /, /ũ/, /ã/, and /õ/ (pp. 21-22). Two vowel clusters (-VV-) as in /moi/ 'potter' and / $\mathrm{p}^{\mathrm{h}} \mathrm{ui} /$ 'father's sister'

\footnotetext{
$3 / \mathrm{prtt}^{\mathrm{h}} \mathrm{o} /$ in Hadoti is 'strong', whereas the same /pətt $\mathrm{h}^{\mathrm{h}} \mathrm{o} /$ in Sarazi is 'plain surface of the earth.' Sarazi is an Indo-Aryan language spoken in district Doda of Jammu and Kashmir State, in the republic of India.
} 
etcetera are very common in Hadoti language, but three vowels clusters are rarely found (p. 22).

Finally, in this chapter, the syllable structure has been discussed in which the vowel is the centre of focus as it remains the nucleus of the syllable, which is mandatory for the syllable structure. The language shows CCCVCCC canonical form as in /ostr/ 'weapon' for /-VCCC/ and /sattwik/ 'good at heart' for /CCCV-/ syllable clusters in each. Hadoti speakers have ability to convert English consonant cluster (CCC-V) /streit/ 'straight' construction to (V-CCC-V) /istreit/ for English word 'straight', as the Hadoti speaker add /i/ sound at the initial position of the English word. Similarly, /sprin/ 'spring' becomes/isprip/ 'spring' and /spravt/ 'sprout' becomes /ispraut/. Hadoti speakers' style of pronouncing the English word is the basic reason for vowel /i/ placement at word initial position especially in English words, which are borrowed in Hadoti. In 'syllable division' section, the author argues that there is no construction like VCCCCV for syllable structure in Hadoti language (p. 23).

\section{Hadoti morphology}

Chapter 3, 'Morphology' (pp. 25-78), deals with word formation processes, inflection, and compounding. It also reflects the division of Hadoti nouns into two genders: masculine and feminine. Animate and inanimate (objects) genders also subsume under these two gender categories, whereas the gender assignment is arbitrary to these objects. Masculine nouns in Hadoti are formed by adding suffixes /o/, /i/, /pər/ and /bo/ to roots as in /ra:d3/ 'secret', /bjapar/ 'business', /pagaV 'mad', and /ga/ 'sing'. On the other hand, feminine nouns are derived by adding the following suffixes /-a/, /-i/, and /-awət/ to the root words /git-a/ 'a Hadoti female name', /pot'-i/ 'a thick book', and /ruk-awət/ 'hurdle'. Affixation is a process in morphology which includes prefixation and suffixation attached to a stem or root to form either derived or inflected words. Prefixes /ə-/ and /ən-/ when add to roots, then the negative meaning is obtained as in /ə-dəV 'no group', and /ən-dzaV 'unfamiliar',

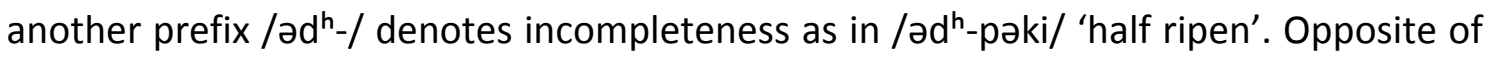
root is obtained when a prefix /ger-/ is affixed to /hadzər/ 'present', then the /ger- 
hadzər/ is an opposite derived word of the root. There are too many prefixes in Hadoti, and all of those cannot be listed here, yet a few are mentioned as: /bəd-/, /be-/, /la-/,

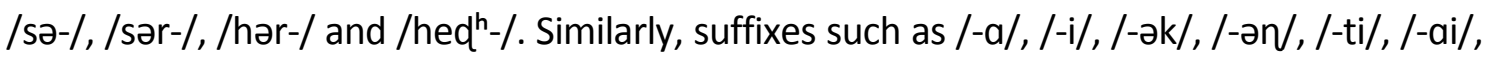
/-at/, /-ap/, /-o/ and /-awət/ are employed in the formation of various derived words.

\begin{tabular}{|c|c|c|c|}
\hline Prefixes & Semanticity & Examples & Gloss \\
\hline /bəd-/ & $\begin{array}{l}\text { Semantically adds negative connotation to } \\
\text { word. }\end{array}$ & /bəd-nam/ & bad reputation \\
\hline /be-/ & $\begin{array}{l}\text { Semantically adds a sense of 'without } \\
\text { something' to word. }\end{array}$ & /be-kar & unemployed \\
\hline /la-/ & $\begin{array}{l}\text { Adds negative meaning to a word when } \\
\text { affixed to root. }\end{array}$ & /la-əlad3/ & incurable \\
\hline /sər-/ & $\begin{array}{l}\text { When added to root gives sense of 'main } \\
\text { thing, or a main person' }\end{array}$ & sər-pənt & village head \\
\hline /sə-/ & $\begin{array}{l}\text { Gives a sense of goodness when affixed to a } \\
\text { root. }\end{array}$ & /sə-put/ & good son \\
\hline /hər-/ & Presents sense of 'each' and 'every'. & /hər-ek/ & everyone \\
\hline /hed $-/$ & $\begin{array}{l}\text { Gives a sense of 'Chief' or 'Head', especially a } \\
\text { person. }\end{array}$ & $\begin{array}{l}\text { /hed } \\
\text { sahab/ }\end{array}$ & chief \\
\hline /səb-/ & $\begin{array}{l}\text { A sense of 'Sub' or 'Under'-a kind of } \\
\text { subordinate in position. }\end{array}$ & $\begin{array}{l}\text { /səb- } \\
d 3 \wedge d z /\end{array}$ & sub-judge \\
\hline$/ b^{h} \partial r-/$ & Sense of completeness & $/ b^{\text {h}} \partial r-p u r /$ & abundant \\
\hline /nə-/ & Meaning 'no' or 'not'. & /nə-kam/ & unaccomplished \\
\hline
\end{tabular}

Table 1. Hadoti Prefixes and their meanings

\begin{tabular}{|l|l|l|l|}
\hline \multicolumn{1}{|c|}{ Suffixes } & \multicolumn{1}{|c|}{ Semanticity } & \multicolumn{1}{c|}{ Examples } & \multicolumn{1}{c|}{ Gloss } \\
\hline /-a/ & Derives a feminine name & /git-a/ & Geeta \\
\hline /-i/ & Feminine noun derivational affix & /ran-i/ & Queen \\
\hline /-ək/ & Any process; either cooking or jumping et cetera & /sidzək/ & cooking process \\
\hline /-əV/ & Performance or condition & /dzut ${ }^{\text {h-ər/ }}$ & leftover food \\
\hline /-ti/ & Activity like chewing, counting, rubbing et cetera & /gən-ti/ & counting \\
\hline /-ai/ & Root ends with performance & /dzot-ai/ & plough \\
\hline /-awət/ & Interruption in a process or gathering & /ruk-awət/ & blockade \\
\hline /-at/ & Root ending with condition & /tənn-at/ & excited \\
\hline /-ap/ & Root ending with performance & /mal-ap/ & meeting \\
\hline /-o/ & Condition and state of action & $/ k^{\text {hos-o/ }}$ & snatched \\
\hline
\end{tabular}

Table 2. Hadoti Suffixes and their meanings 
Pronouns in Hadoti are classified under personal, relative, interrogative, and honorific. Hadoti personal pronouns are 'first person' which comprises /mũ/ 'I.1.SG',

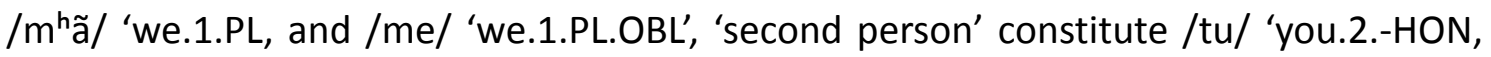
$/ \mathrm{t}^{\mathrm{h}} \mathrm{u} /$ 'you.2.SG.M', /thã/ 'you.+HON', /tẽ/ 'you.+HON.SG' and /thẽ/ 'you.+HON.PL'; and 'third person' pronouns are /u/ 'he.3.NOM.SG, /we/ 'he.3.NOM.PL' and /wa/ 'she.3.NOM.SG'. Relative pronouns are /dzjo/ 'that.REL.M', /dzja/ that.REL.F', and /dze/ 'that.M/F.PL'; interrogative pronouns are /køW and /kãi/; regular relative pronouns are /u/ and /so/ 'NOM.SG/PL' and honorific pronoun is /ap/ 'you.+HON'. Hadoti also reveals definitive pronoun comprising of proximate /jo/ 'NOM.SG.M', /ja/ 'NOM.SG.F' and /je/ 'NOM.PL.M/F', and remote /u/, /wa/, and /we/. Indefinite pronoun is /koi/ 'someone'.

The section 'Hadoti verbs' discusses verbs with their inflections. The author of the book argues that the simple verb forms inflect for the present, past and future tense in all numbers and genders (p. 52). The verbal complex forms are dependent on two parameters: the participles and the auxiliaries. The auxiliary markers are added to base forms of the verb to form aspectual forms. The base form of verb $/ k^{\text {h }} a /$ 'eat' takes /-we/ suffix to form the present participle, as it becomes / ${ }^{h} a-w \varepsilon /$ 'eats'. The past participle is obtained out by suffixing /-to/ and /-ti/ for masculine and feminine, as in

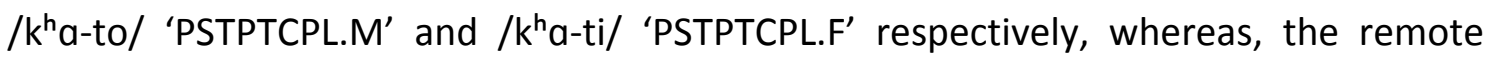
past participle verb take /-gjo/ and /-gji/ for masculine and feminine, as in / $\mathrm{k}^{\mathrm{h}} \mathrm{a}$-gjo/ 'eat.PSTPTCPL.M' and / $\mathrm{k}^{\mathrm{h}} \mathrm{a}$-gji/ 'eat.PSTPTCPL.F'. Auxiliary verbs in Hadoti are: the present $/ \mathrm{t} \int^{\mathrm{h}} \varepsilon /$ 'to be', the past $/ \mathrm{t} \int^{\mathrm{h}} \mathrm{O} /$ (masculine) and $/ \mathrm{t} \int^{\mathrm{h}} \mathrm{i} /$ (feminine), and /hove/ to become' takes /-ga/ suffix to form future auxiliary, as it forms /hove-ga/ 'will happen' (p. 54). Hadoti has two auxiliary roots $/ \mathrm{t} \mathrm{f}^{\mathrm{h}} \varepsilon /$ 'to be' and /ho/ which are complementary to each other. Tables 3 and 4 depict the auxiliary verb $/ \mathrm{t}^{\mathrm{h}} \varepsilon /$ and $/ \mathrm{ho} / \mathrm{as}$ : 


\begin{tabular}{|c|c|c|c|c|}
\hline Hadoti Auxiliary & \multicolumn{2}{|c|}{ Present } & \multicolumn{2}{|c|}{ Past } \\
\hline \multirow{2}{*}{ First Person } & $\begin{array}{l}/ \mathrm{t} \mathrm{S}^{\mathrm{h}} \mathrm{u} / \\
\mathrm{SG}\end{array}$ & $\begin{array}{l}/ \mathrm{t} \int^{\mathrm{h}} \tilde{a} / \\
\mathrm{PL}\end{array}$ & $\begin{array}{l}/ \mathrm{t}^{\mathrm{h}} \mathrm{O} / \\
\text { M.SG }\end{array}$ & $\begin{array}{l}\text { /t } \int^{h \mathrm{~h}} / \\
\text { F.SG }\end{array}$ \\
\hline & & & $\begin{array}{l}/ \mathrm{t}^{\mathrm{h}} \mathrm{a} / \\
\mathrm{M} . \mathrm{PL}\end{array}$ & $\begin{array}{l}/ \mathrm{t} \int^{\mathrm{h}} \mathrm{i} / \\
\text { F.PL }\end{array}$ \\
\hline Second Person & $\begin{array}{l}/ \mathrm{t} \int^{\mathrm{h}} \varepsilon / \\
S G\end{array}$ & $\begin{array}{l}/ \mathrm{t} \int^{\mathrm{h}} \mathrm{O} / \\
\mathrm{PL}\end{array}$ & & \\
\hline Third Person & $\begin{array}{l}/ \mathrm{t} \int^{\mathrm{h}} \varepsilon / \\
S G\end{array}$ & $\begin{array}{l}/ \mathrm{t} \int^{\mathrm{h}} \varepsilon / \\
\mathrm{PL}\end{array}$ & & \\
\hline
\end{tabular}

Table 3. Hadoti auxiliary $/ \mathrm{t} \int^{\mathrm{h}} \varepsilon /$

\begin{tabular}{|c|c|c|}
\hline Hadoti Auxiliary & \multicolumn{2}{|c|}{ Future } \\
\hline \multirow[t]{2}{*}{ First Person } & $\begin{array}{l}\text { /hoũgu/ } \\
\text { M.SG }\end{array}$ & $\begin{array}{l}\text { /hoũgi/ } \\
\text { F.SG }\end{array}$ \\
\hline & $\begin{array}{l}\text { /howegã/ } \\
\text { M.PL }\end{array}$ & $\begin{array}{l}\text { /howrgi/ } \\
\text { F.PL }\end{array}$ \\
\hline \multirow[t]{2}{*}{ Second Person } & $\begin{array}{l}\text { /howego/ } \\
\text { M.SG }\end{array}$ & $\begin{array}{l}\text { /howrgi/ } \\
\text { F.SG }\end{array}$ \\
\hline & $\begin{array}{l}\text { /howega/ } \\
\text { M.PL }\end{array}$ & $\begin{array}{l}\text { /howrgi/ } \\
\text { F.PL }\end{array}$ \\
\hline
\end{tabular}

Table 4. Hadoti auxiliary /ho/

For 3rd person future auxiliary, masculine singular and plural are /howega.SG/ and /howega.PL/, and feminine singular and plural are /howegi.SG/ and /howegi.PL/ respectively. In Hadoti, progressive aspect markers for masculine and feminine are /rjo/ and /rji/ separately employed, shown in examples as: /dza-rjo/ 'go.PROG.M' and /dza-rji/ 'go.PROG.F'. Perfective aspect shows complex construction having 'verb+ /jo/' and auxiliaries $/ \mathrm{t} \int^{\mathrm{h}} \varepsilon /$ and $/ \mathrm{t} \int^{\mathrm{h}} \mathrm{a} /$ are employed for the present and the past tenses.

Hadoti moods are as: infinitive; indicative; imperative and conditional. The infinitive mood morph /-bo/ when affixed to the verb root; it results into the /X-bo/, where $X$ is any root verb, for instance, /ləd-bo/ 'to fight', / $k^{\text {h }} \mathrm{a}$-bo/ 'to eat', and /pəd' bo/ 'to read'. Indicative mood asserts or indicates an action in time. The indicative

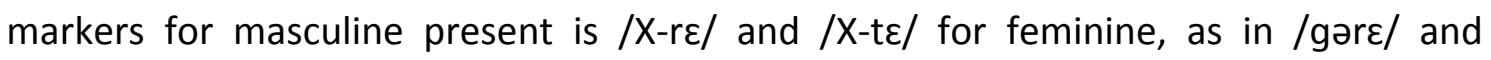
/gərte/. For past indicative, the markers /-jo/ and /-jã/ is applied to masculine singular and plural verbs such as /gir-jo/ and /gir-jã/, whereas in case of feminine, the markers are as: /-i/ and /-ĩ/ as in /gir-i.SG.F/ and /gir-ĩ.PL.F/. Imperative mood mentions the requests and commands, such as $/ \mathrm{bet}^{\mathrm{h}} \mathrm{o} / \mathrm{s}$ 'st.IMP' in present and $/ \mathrm{k}^{\mathrm{h}} \mathrm{el}$-je/ 
'play.FUT.IMP' and /adz-jo/ 'come.FUT.IMP' in future imperatives respectively. Conditional mood in Hadoti is expressed using markers such as /dzjo/ 'if'... /-to/ 'be'; it is 'if and then' conditional form, and derives the form as /ho-to/ 'be.CON'. Where, /to/ is 'then' conditional.

'Compound verbs' section reveals the following Hadoti compound verbs, with the combination of 'verb + verb' as shown in examples, /lj+abo/ 'take + go', /dj + abo/

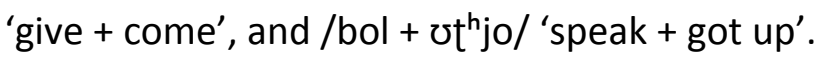

Hadoti verbs inflect for all the roots to which the following markers are applied. The verb inflection for root /t $\int \mathrm{al} /$ ' walk' follows as:

\begin{tabular}{|c|c|}
\hline Root & 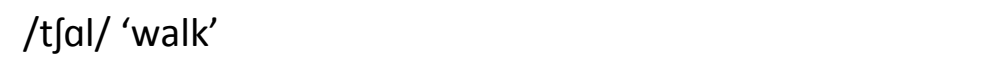 \\
\hline Infinitive & /t fal-bo/ 'to walk' \\
\hline Imperfect Participle & /t $\int a l-b \varepsilon /$ 'walks' \\
\hline Perfect Participle & /t fal-jo/ 'walked' \\
\hline Causative-I & /t fal-abo/ 'to make someone walk' \\
\hline Causative-II & /t fal-wabo/ 'to make someone make someone else walk' \\
\hline
\end{tabular}

\section{Hadoti Syntax}

Chapter 4, 'Syntax' (pp. 79-99), explains the various types of sentences and their typologies. Specifically, four types of sentences namely interrogative, imperative, declarative, and exclamatory are discussed in detail.

A sentence is said to be a declarative one when it makes a statement, affirms a statement which is a Stative one in context to speech act. The sentence follows as: /mñ boljõ/ 'I speak.PST.SG.M', in which the subject-verb word order is noticed (p. 79). Contrastively, a sentence /ram dzawega/ 'Ram will go' is declarative in form, but if the sentence has rising intonation, a prosodic feature, then the same declarative sentence automatically gets converted into interrogative sentence (p. 81). 
Hadoti interrogative sentences serve two functions: firstly, the sentences ask a question and secondly, the sentences ask for to obtain further information. Furthermore, Dwivedi argues that the interrogative sentences are of two kinds: 'yes-no questions' and 'question-word questions'. Here 'yes-no questions' are further subdivided into two types; type 1 is neutral yes-no questions, formed by optional assignment of question word /kai/ 'who' in the sentence initial position of a declarative sentence, and type 2 is leading yes-no questions, obtained by adding /na/ or / ni/ both meaning 'not' at the end position of a sentence, and then it serves as a question tag shown as in this sentence: /dzəgəh $t \int^{h} i t \int^{h} \varepsilon$ na/ 'The place is good, isn't it?' When another negative marker precedes the /na/ or /ni/, then the sentence takes the negative form, and the negative answer is sought. The sentence follows as: /dzəgəh $\mathrm{t} \int^{\mathrm{h} i}$ koni $\mathrm{t} \int^{\mathrm{h}} \varepsilon \mathrm{ni} /$ 'The place is not good, is it?'

The question-word question in English begin with the Wh-type words such as 'when, why, where, what', etc. which the author mentioned as k-sound words that form the questions. Similarly the question words in Hadoti are /kai/ 'what', /kun 'who', /kisjo/ 'which', /kəthe/ 'where', /kjũ/ 'why', /kesja/ 'how', /kitta/ 'how much', /kinne/ 'in what direction', and /ked hak/ 'when'. All the k-type (wh-type questions in English) questions are formed using these types of words in Hadoti constructions (p. 83).

Imperative sentences in Hadoti are of five kinds such as 'the basic imperative; the future imperative; the subjunctive imperative; the obligative imperative; and the prohibitive imperatives. The basic imperative takes /tu/ 'you' a singular non-honorific and $/ t^{\text {hẽ }} /$ plural honorific second person subject. Subject ellipsis is also seen in the basic imperatives, such as: /ja $t \int i t t^{h_{i}}$ pəd $^{\mathrm{h}} \mathrm{o} /$ 'Read this letter.' Future imperative is every time designated by the verb employed in construction, as in /pat ${ }^{\mathrm{h}} \mathrm{e}$ adzo/ 'come later'.

The subjunctive construction expresses a suggestion, wish, or intention rather than a command or request as given in a sentence / ram bh $b^{\text {h }}$ ləni t t ${ }^{\text {h }}$ ajdze/ 'Ram should participate.' The obligative imperatives reflect moral and epistemic obligations in which the compound verbs are employed, in a construction as $/ \mathrm{m}^{\mathrm{h}} \mathrm{i}$ wa mastərni ri

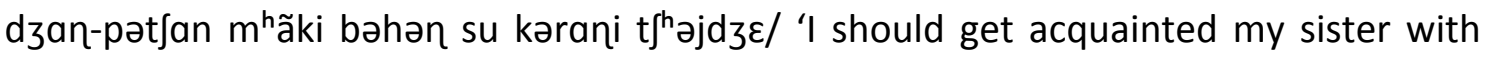
the new teacher', here the compound verb is /dzan-pətfan/ literally 'know-identify' 
which in fact is taken as 'acquaintance'. In addition, the author of the manuscript advocates that the obligative constructions do not take nominative subjects, and if done so, the construction becomes ungrammatical one (p. 85). To avoid ungrammaticality, an ellipsis process should be followed.

In the prohibitive construction of Hadoti, the negative particle either /na/ or /mət/ 'not' is applied to imperative sentences, and is usually placed before the verb. The construction is represented as / $k^{\text {h}}$ ət hi mət/na pədo/ 'Don't read the letter.' There is an exception to the use of negative particle /koni/ 'not' which cannot be used in imperative prohibitive constructions. If this exception is not followed, the construction will result into ungrammaticality (p. 86).

Exclamatives in Hadoti serve the purpose of expressing emotions. For instance, /səmbəl/ is a word that functions as exclamative one, meaning 'be careful'. The author states that when a declarative statement such as /mama dzi aja/ 'uncle came' is duplicated fully, the construction becomes exclamative one as in /mama dzi aja-mama dzi aja/ 'uncle came!' (p. 86). Exclamative particles /əre/ 'oh', /oje/ 'oh', /ũ-hũ/ 'no', and $/ \mathrm{r} \varepsilon /$ 'alas' are employed to form exclamative sentences, moreover these constructions express strong emotional reaction over the speaker's presupposition for quality of truthfulness.

The Hadoti syntax of direct and indirect speech is not different from each other. Syntactically, no particle or quotative marker is used to differentiate between direct and indirect speech. In narration, the quoted and reported material is held in an embedded sentence preceded by the complementizer / $\mathrm{ki}$ / 'that' which is subordinate relative to the higher verb of the sentence (p. 87). Use of / $\mathrm{ki}$ / 'that' is not limited to the quotation, but in direct speech, it doesn't attempt to reproduce actual words (p. 89).

Subordination is the process in which the two clauses are conjoined where one clause subordinates the other. Finite and non-finite verbs are made use of in subordination process. Additionally, the subordinate (complementizer) marker occupies the first place in the subordinate clause, and secondly, the main clause precedes the subordinate clause, contrastively, if the main clause follows the subordinate clause, the shifting of focus is noticed. 
A complement clause in Hadoti realizes a sub-categorization restriction on an associated lexical head, which acts either as a complement of subject or object as in example, $/ \mathrm{k}^{\mathrm{h}} \varepsilon$ to di $\mathrm{m}^{\mathrm{h}} \mathrm{n} \varepsilon$ jo $\mathrm{g}^{\mathrm{h}} \mathrm{od}^{\mathrm{h}} \mathrm{O} \mathrm{m}^{\mathrm{h}}$ aro $\mathrm{t} \mathrm{f}^{\mathrm{h}} \varepsilon /$ 'I have already said that this horse is mine.' In this sentence, /jo $\mathrm{g}^{\mathrm{h}} \circ \mathrm{d}^{\mathrm{h}} \circ \mathrm{m}^{\mathrm{h}}$ aro $\mathrm{t} \mathrm{f}^{\mathrm{h}} \varepsilon /$ 'this horse is mine' is a complement of the complex verb $/ k^{\mathrm{h}} \varepsilon$ to di/ 'already said'. Also, the Hadoti complementizer /ki/ shows

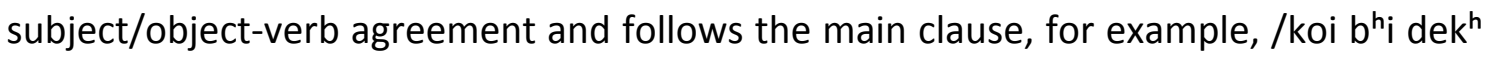
sək $\varepsilon \mathrm{t}^{\mathrm{h}} \varepsilon$ ki u bimar $\mathrm{t} \int^{\mathrm{h}} \varepsilon /$ 'anyone can see that he is sick' (pp. 90-91).

Two kinds of relative clauses in Hadoti are noticed: finite relative clause with subject-verb agreement and non-finite participial relative clause revealing the nonfinite form of the verb. The primary relative clause marker /dzjo/ 'who/which' is placed before the relativized element and the correlative marker /so/ 'that' is positioned at the beginning of the head noun, as in /so mastərni nəwi $t \int^{\mathrm{h}} \varepsilon d 3 j a-k i$ dzanpət ${ }^{\text {h}}$ an mhãki bəhən su kərani t thajdze/ 'I should make my sister get acquainted with the new teacher'. In this sentence, /mastərni nəwi t $\int^{h} \varepsilon /$ 'the teacher is new' is the main clause, whereas the rest of the part of this sentence is a relative clause (p. 92). Here the participial relative clause is obtained by eliminating the relativized noun phrase, and changing the verb into participial form by adding the /-to/ to the verb /ro/ 'cry' for the present participle, /-ərio/ to the verb /-ro/ 'cry' for the past and /-halo/ 'who' an agentive like construction for the agentive participle (p. 92).

Hadoti admits the following coordinate conjunctions; /er/ 'and', adversative /pə巾 'but', disjunctive /kع/ 'or', or it is /ja/ 'or', and negative disjunction /nə - nə/ 'neither...nor' (p. 95).

Sentential negation in Hadoti occurs by employing four negative particles, such as /koni/, /koi nə/, /na/, and/nei/. In brief, /koni/ and/koi nə/ are unmarked negative particles and are corresponding to English 'not'. Whereas negative particles /na/ and /nei/ are applied to subjunctive, imperative, conditional, neither-nor construction, and infinitive phrases. A few distributive properties of the negative particles are given in examples as: /həri $k^{\text {h }} a$ li əkela nə awega/ 'Hari will not come alone only', and /ũ kal susral nə gjo/ 'He didn't go to his father-in law's house'. Considering these two sentences, it is construed that the negative particle appears at pre-verbal position in a negative sentence construction (pp. 98-99). 


\section{Conclusion}

Chapter 5, 'Conclusion' (pp. 100-112), embodies certain facts about Hadoti language which are supportive enough to categorize the language as an independent one, rather than being a dialect of Rajasthani and Hindi. The author claims the following supportive arguments as:

"Rajasthani is not a language, but a geographical area, and Rajasthani is not defined as a language in the constitution of India. S. N. Sadasivan, a Historian mentioned in his book A Social History of India that modern Hindi is a blend of such North Indian dialects as Maithili, Awadhi, Khadiboli, Vrijbhasha, Magadhi, Aradhmagadhi, and Hadoti, spoken in Kota (Rajasthan) (p.100)".

This quoted reference clarifies doubts that the existence of Hadoti was much earlier than Hindi. Morality of ethnic people of Hadoti region is explicitly revealed by the author in socio-cultural aspects, especially in the proverbs of Hadoti. Here in this text, Dwivedi discusses in detail the various aspects of Hadoti proverbs, such as proverbs in society, caste, gender, religion, education, agriculture, and history. Tense and aspect is also discussed in the said proverbs.

The author has followed the Peuke's approach to proverbs, and based on this approach, Hadoti proverbs have been categorized into five patterns. The patterns are as: (1) If $X$ then $Y,(2)$ Like $X$, Like $Y,(3)$ No $X$ without $Y$, (4) Better $X$ than $Y$, and (5) One $X$ does not make a $Y$. In addition, two more patterns are ' $X$ happens, but why does not happen' and ' $X$ positive, $Y$ negative' (p. 103). It is impossible to discuss all kinds of proverbs here, even though some are discussed for understanding of Hadoti cultural aspects. The discussion follows as:

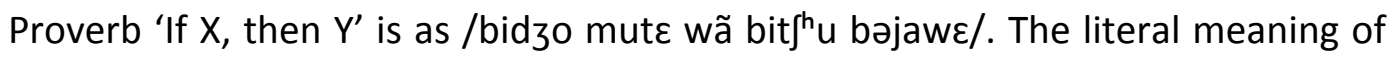
this proverb is 'if a businessman pisses, then there meets a scorpion', and its proverbial meaning is 'no business flourishes without profit.' The proverb 'Like $\mathrm{X}$ like $\mathrm{Y}^{\prime}$ is /dzet ${ }^{\text {h }}$ ko so pet ko/, it literally means 'husband's brother's child is like one's own child', and it connotes that every child should be treated as if the child is someone's own. 


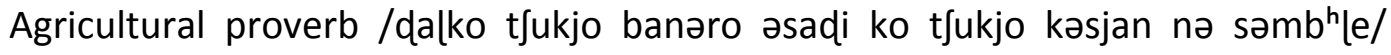
denotes 'a monkey that misses a branch; and a farmer who misses a monsoon, none could be safe in recovery', and connotes as 'don't miss a chance'.

Society related proverbs have reflected caste system that still prevails among the speakers of Hadoti. One befits as /dadzma ki dari dzat $k^{\mathrm{h}}$ ajã pat $\int^{\mathrm{h}} \varepsilon$ mare lat/ meaning 'a Dajma Brahmin deceives everyone'. In general, it infers that one should not trust a Brahmin. ${ }^{4}$ Next proverb is related to Rajput sect of Hinduism; the proverb follows as:

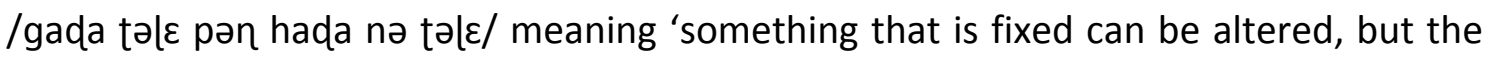
decision of Hada Rajput cannot be changed'. Its derived meaning can be as: 'Hada Rajput is a man of words and such men are rare in the present day world.' Other casts such as Baniya (merchants), Jat (agricultural community), and $\mathrm{Nai}^{5}$ (Barber) are also mentioned in the text (pp. 108-109).

Proverbs related to Hadoti women are also discussed by Dwivedi in his manuscript. One of the proverbs is as /kəwari kənja ka $\mathrm{t}^{\text {h } \partial t i s ~ w ə r / ~ ' a n ~ u n m a r r i e d ~ g i r l ~}$ has plentiful possibilities to marry anyone desired groom'. It is intended as 'a single person would have many choices to make his/her career'. A morality based proverb /sãt $i$ ãt koi ne/ denotatively, it is 'truthful person is always fearless', which connotes 'truth triumphs!' Proverbs pertaining to education, history, psychology, and many more have been discussed in with a great deal of expression.

Finally, I would say that this is a unique kind of book written on Hadoti, a macro language of Rajasthan, in the Republic of India. The book offers linguistic field techniques and insightfully depicts what is involved in documenting a macro language. Widely speaking, this book is written for adding knowledge to the linguistic literature as well as enriching the discipline of Field Linguistics. This book on grammar emphasizes special features of Hadoti. In brief, this manuscript fulfils the needs of the juvenile language learners as well as provides valuable information for the linguists and the common readers. Overall, this text aims at providing wide-ranging information

\footnotetext{
${ }^{4}$ Brahmin is a caste in Hinduism acting as teachers and promoters of sacred learning across the generations.

${ }^{5}$ In Gujarat State, the Nai are known by the name Valand, and many of them have adopted the name 'Sharma', and preserved themselves as 'Brahmin'.
} 
on diverse aspects of Hadoti phonology, morphology, syntax, and paremiology along with its unique features and historical backdrop. Revitalization of Hadoti has been carried out with great care, and I wish the author a grand success!

\section{References}

DIXON, Robert M.W. (1994) Ergativity, Cambridge: Cambridge University Press.

DWIVEDI, Amitabh Vikram (2015) "Proverbs and Identity: A Study of Proverbs", Entrepalavras, $5,1,8-19$.

SAdASIVAN, S.N. (2000) "A Social History of India”, New Delhi: APH Publishing.

CENSUS OF INDIA <http://www.indiaonlinepages.com/population/rajasthan-population.html> (Accessed 10 May 2016).

\section{Appendix I. Population of Rajasthan 2011}

\section{Distribution of Population, Decadal Growth Rate, Sex-Ratio and Density of population 2011}

\begin{tabular}{|c|c|c|c|c|c|c|}
\hline \multirow[t]{2}{*}{ State/ District } & \multicolumn{3}{|c|}{ Population in 2011} & \multirow{2}{*}{$\begin{array}{l}\text { Percentage } \\
\text { Decadal } \\
\text { Growth } \\
\text { Rate of } \\
\text { Population } \\
\text { 2001-11 }\end{array}$} & \multirow{2}{*}{$\begin{array}{l}\text { Sex Ratio } \\
\text { (No. of } \\
\text { Females } \\
\text { per } 1000 \\
\text { Males) } \\
2011\end{array}$} & \multirow{2}{*}{$\begin{array}{c}\text { Population } \\
\text { density per } \\
\text { Sq. Km }\end{array}$} \\
\hline & Person & Male & Female & & & \\
\hline Rajasthan & 68621012 & 35620086 & 33000926 & 21.44 & 926 & 201 \\
\hline Ganganagar & 1969520 & 1043730 & 925790 & 10.06 & 887 & 179 \\
\hline Hanumangarh & 1779650 & 933660 & 845990 & 17.24 & 906 & 184 \\
\hline Bikaner & 2367745 & 1243916 & 1123829 & 24.48 & 903 & 78 \\
\hline Churu & 2041172 & 1053375 & 987797 & 20.35 & 938 & 148 \\
\hline Jhunjhunun & 2139658 & 1097390 & 1042268 & 11.81 & 950 & 361 \\
\hline Alwar & 3671999 & 1938929 & 1733070 & 22.75 & 894 & 438 \\
\hline Bharatpur & 2549121 & 1357896 & 1191225 & 21.39 & 877 & 503 \\
\hline Dhaulpur & 1207293 & 654344 & 552949 & 22.78 & 845 & 398 \\
\hline
\end{tabular}


Dialectologia 18 (2017), 189-203.

ISSN: 2013-2247

\begin{tabular}{|c|c|c|c|c|c|c|}
\hline Karauli & 1458459 & 784943 & 673516 & 20.94 & 858 & 264 \\
\hline $\begin{array}{l}\text { Sawai } \\
\text { Madhopur }\end{array}$ & 1338114 & 706558 & 631556 & 19.79 & 894 & 297 \\
\hline Dausa & 1637226 & 859821 & 777405 & 23.75 & 904 & 476 \\
\hline Jaipur & 6663971 & 3490787 & 3173184 & 26.91 & 909 & 598 \\
\hline Sikar & 2677737 & 1377120 & 1300617 & 17.04 & 944 & 346 \\
\hline Nagaur & 3309234 & 1698760 & 1610474 & 19.25 & 948 & 187 \\
\hline Jodhpur & 3685681 & 1924326 & 1761355 & 27.69 & 915 & 161 \\
\hline Jaisalmer & 672008 & 363346 & 308662 & 32.22 & 849 & 17 \\
\hline Barmer & 2604453 & 1370494 & 1233959 & 32.55 & 900 & 92 \\
\hline Jalor & 1830151 & 937918 & 892233 & 26.31 & 951 & 172 \\
\hline Sirohi & 1037185 & 535115 & 502070 & 21.86 & 938 & 202 \\
\hline Pali & 2038533 & 1025895 & 1012638 & 11.99 & 987 & 165 \\
\hline Ajmer & 2584913 & 1325911 & 1259002 & 18.66 & 950 & 305 \\
\hline Tonk & 1421711 & 729390 & 692321 & 17.33 & 949 & 198 \\
\hline Bundi & 1113725 & 579385 & 534340 & 15.7 & 922 & 193 \\
\hline Bhilwara & 2410459 & 1224483 & 1185976 & 19.27 & 969 & 230 \\
\hline Rajsamand & 1158283 & 582670 & 575613 & 17.89 & 988 & 302 \\
\hline Dungarpur & 1388906 & 698069 & 690837 & 25.39 & 990 & 368 \\
\hline Banswara & 1798194 & 908755 & 889439 & 26.58 & 979 & 399 \\
\hline Chittaurgarh & 1544392 & 784054 & 760338 & 16.09 & 970 & 193 \\
\hline Kota & 1950491 & 1023153 & 927338 & 24.34 & 906 & 374 \\
\hline Baran & 1223921 & 635495 & 588426 & 19.82 & 926 & 175 \\
\hline Jhalawar & 1411327 & 725667 & 685660 & 19.57 & 945 & 227 \\
\hline Udaipur & 3067549 & 1566781 & 1500768 & 23.63 & 958 & 242 \\
\hline Pratapgarh* & 868231 & 437950 & 430281 & 22.84 & 982 & 211 \\
\hline
\end{tabular}

Note: Districts namely Bundi, Kota, Barn, and Jhalawar of Rajasthan State comprises the population of Hadoti Speakers. 